ISSN 1112-9867

\title{
SMART BOOK LOCATOR SYSTEM BASED ON GEOGRAPHIC INFORMATION SYSTEM AT PERPUSTAKAAN TUN ABDUL RAZAK 1, UITM SHAH ALAM MALAYSIA
}

\author{
N. Ya'acob ${ }^{1,2, *}$, S. Abdullah ${ }^{1}$, A. L. Yusof ${ }^{1,2}$, N. F. Naim ${ }^{1}$ and M. A. Zainali ${ }^{1}$ \\ ${ }^{1}$ Faculty of Electrical Engineering, Universiti Teknologi MARA, 40450 Shah Alam, Selangor, \\ Malaysia \\ ${ }^{2}$ Wireless Communication Technology (WiCoT), Faculty of Electrical Engineering, Universiti \\ Teknologi MARA, 40450 Shah Alam, Selangor, Malaysia
}

Published online: 17 October 2017

\begin{abstract}
Implementation of virtual library on PerpustakaanTun Abdul Razak 1 (PTAR 1), which used to be packed with students most of the time has led to less frequent visitors to the physical library. Although the online database, Online Public Access Catalogue (OPAC), eases the burden of users to inquire the availability and location of desired references, library users still have to go to the library and search through the endless cabinets to locate and retrieve the materials. This study proposes a system called Smart Book Locator System (SBLS), which incorporates Geographic Information System (GIS) to assist users in visualising and navigating them to the location of the materials.
\end{abstract}

Keywords: OPAC; GIS; SLBS; virtual library.

Author Correspondence, e-mail: norsuzilayaacob@yahoo.com doi: http://dx.doi.org/10.4314/jfas.v9i5s.22 


\section{INTRODUCTION}

\subsection{Virtual Library and OPAC}

A library is a collection of sources of information and similar resources, made accessible to a defined community for reference or borrowing [1]. PerpustakaanTun Abdul Razak 1 (PTAR 1) is a library, which is located at level 4 and 5 of faculty of engineering at UniversitiTeknologi MARA (UiTM) in Malaysia, offering variety of facilities to its users. Prior to implementation of virtual library at UiTM, PTAR 1 used to be packed with students and visitors most of the time, particularly during study week and examination period. The success of virtual library on PTAR 1 has led to less users visiting the library.

According to [2], open source system presents new opportunity for libraries to engage in the technology that they offer and to deliver functionally rich solutions. This new generation of open source system provide layers of open services to support an increasingly digital, mobile, client community of the libraries.

One of the features of virtual library at UiTM is the Online Public Access Catalogue (OPAC), which is an online database system, developed to provide standalone catalogue of books and other reference materials within its network for public access. Its ultimate goal is to deliver comfort and confidence to all level of users when navigating through the system for information [3]. In education sector, amongst the first few large-scale online catalogues developed were for Ohio State University in 1975 and Dallas Public Library in 1978. The OPAC system developed for UiTM's network of libraries has interface as illustrated in Fig. 1. The catalogue is designed in a way such that each query in the database would return the basic reference information of desired material, namely author, published year, availability and call number. Call number is the reference number used to indicate storage of the material at the library.

Eventually, users will have to visit the library and wander through the cabinets to retrieve the desired material based on call number displayed in OPAC system. For experience visitors, who are already familiar with the layout of the library, the search for materials would be relatively easy, compared to new visitors. Novice users would take longer time to find the materials and to some, the experience may hinder them from using OPAC in the future. 


\section{OPAC}

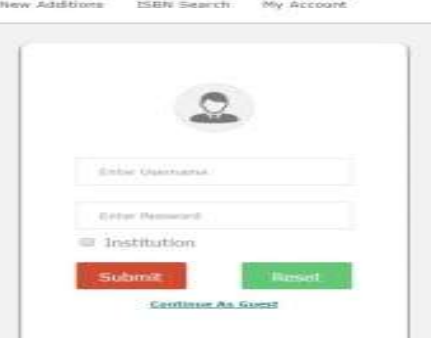

Fig.1.Interface of Unit Web OPAC system for UiTM

This limitation of OPAC system encourages opportunities for further enhancement of the system particularly in the area of facilitating users to find the exact location of the material [4]. In other areas, in [5-6] proposed to unfold the potential achievable by using artificial neural networks, in profiling the user, in terms of competences and preferences, development of educational pathways desired and professional skills to achieve. Similar approach can be applied in the area of expediting time consumption to retrieve material in the library.

\subsection{Geographical Information System}

Geographical Information System (GIS) is a framework intended to catch, store, control, break down, oversee and present a wide range of spatial or land information. It has been widely used as management tool in many fields. Applying GIS in the current virtual library system would allow digitally mapping the library [7], and therefore further utilised as inventory management and navigation tools. Mapping of participating libraries throughout the state of that served as virtual "entry portals", as their network to gather the information regarding the details of inventory [8-9].

This paper proposes to develop an online portal, which integrates OPAC and GIS, enabling visualisation of the library and providing navigation path to the location of materials in addition of material search query. The proposed portal is called Smart Book Locator System (SBLS) and its main objective is to assist library users locating reading materials with less time consumption hence improving library management system.

\section{METHODOLOGY}

\subsection{Material}

For this study, software Adobe Dreamweaver, ArcGIS 10.1, ArcGIS Server and ArcGIS 
Viewer for Flex are used to design, visualise the architecture of the library and ultimately create the proposed SBSL. PTAR 1 is the chosen as target library amongst UiTM's network of libraries.

\subsection{Method}

The study involves seven stages as outlined in flowchart shown in Fig. 2. The first two stages are preliminary study and data collection. Data with regard to the architecture and arrangement of target library, in this case PTAR 1 is collected. Information of reference materials available at PTAR 1 as in OPAC is also retrieved during this stage. Fig. 3 and 4 present the floor plan of PTAR 1 library on level 4 and 5 respectively.

The third stage is digitization, which is a process of converting raster data into vector form. The floor plan of PTAR 1 is digitized using ARCGIS software. In this stage, spatial data is extracted and converted into shape files. Accurate digitization is essential to represent the shape and architecture of the building. In this process, 'cut polygons' and 'auto complete polygon' tools are used to minimize and prevent errors such as overlap and gap between borders. The 'cut polygons' tool allows shape, in this study circle shape, cutting from one or more selected polygons. 


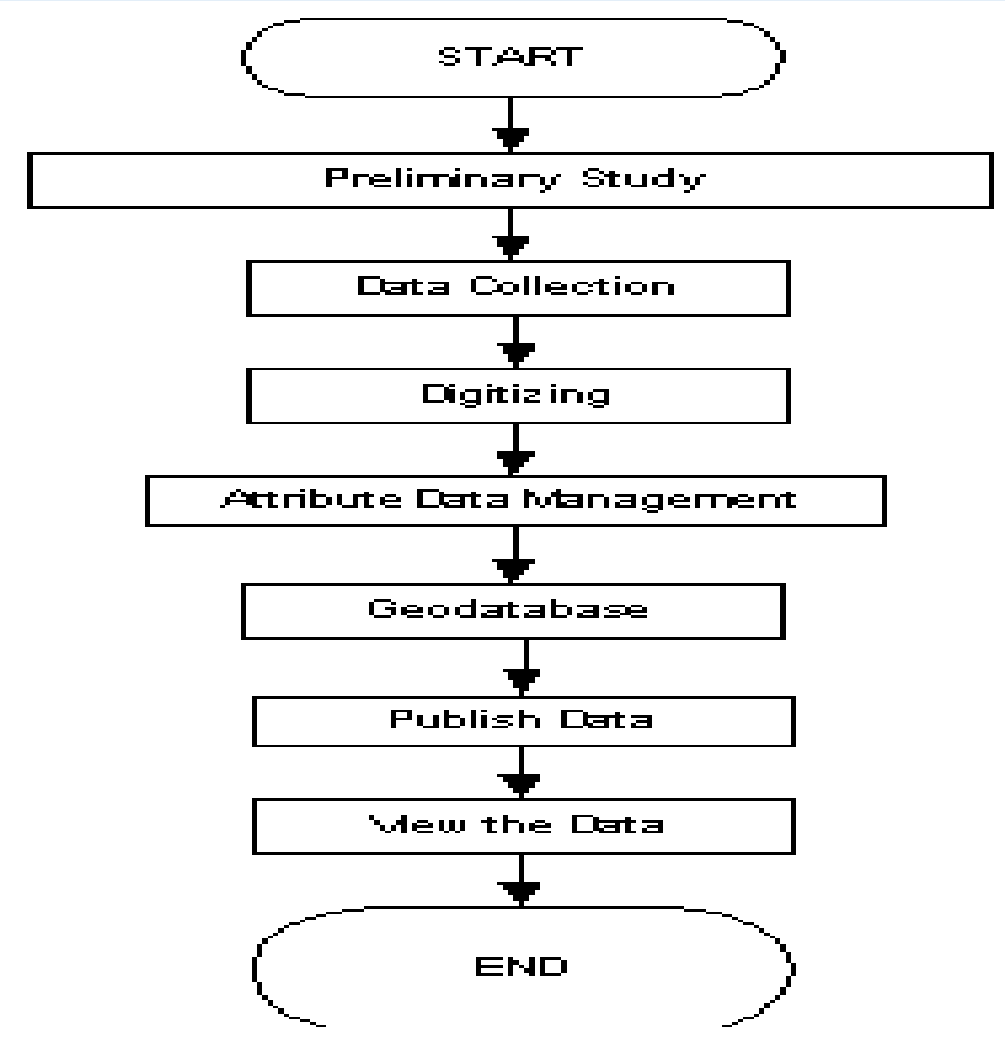

Fig.2. Outline methodology flowchart

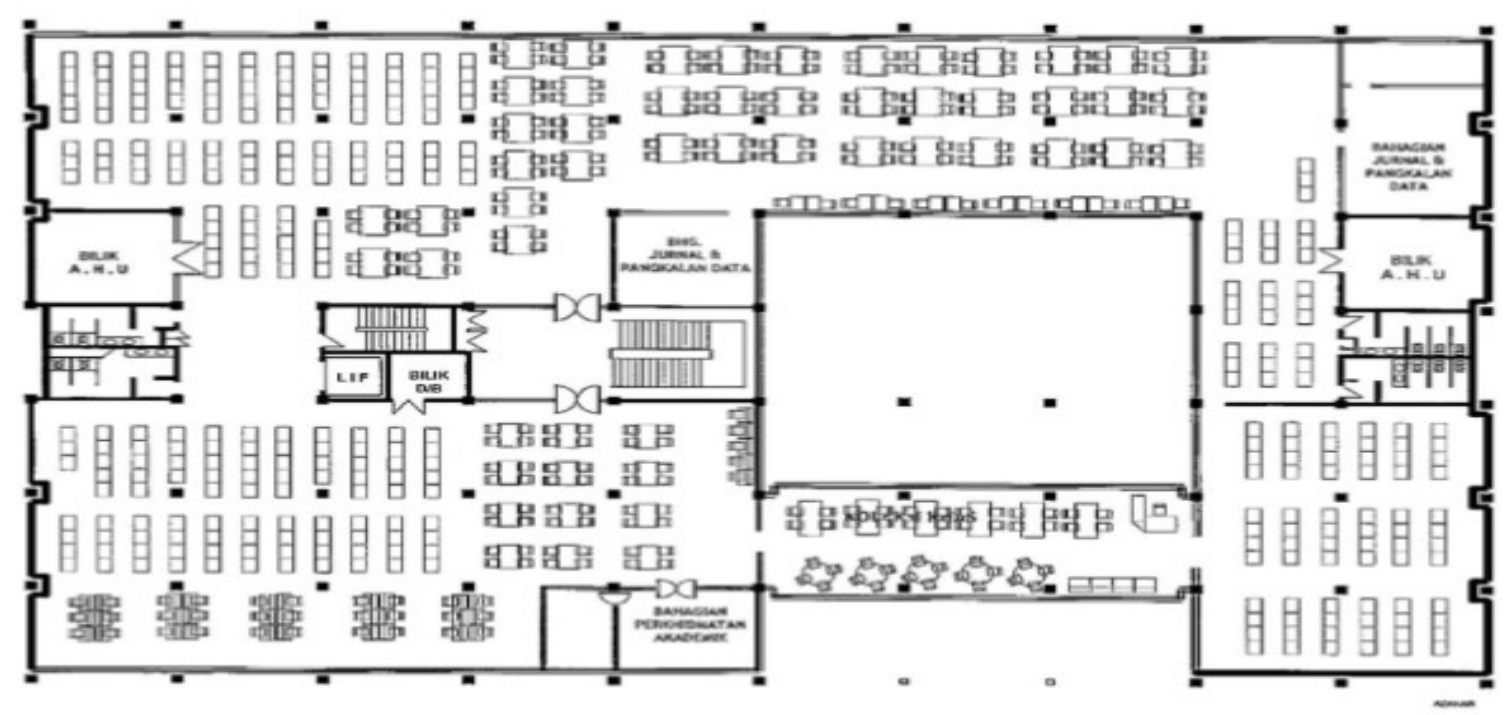

Fig.3.Floor plan-scanned copy of Level 4 PTAR 1 


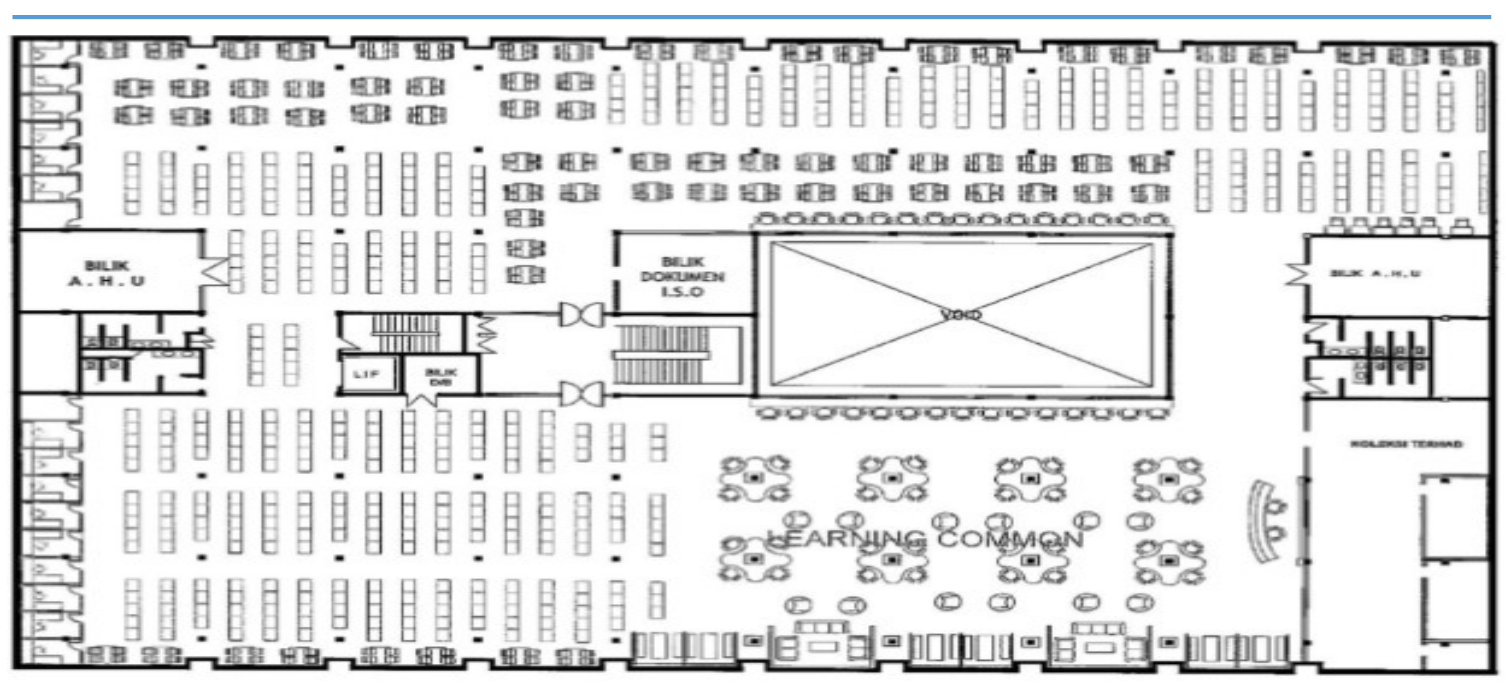

Fig.4.Floor plan-scanned copy of Level 5 PTAR 1

Attribute data management is a process to insert information of materials. In this stage, the information of reference materials available in PTAR 1 retrieved in stage 2 is compiled and arranged in a database. Each reference material is then linked to respective cabinets based on its call number. Navigation route is then created to start from a PC, which is designated for OPAC usage at PTAR 1 to each reference materials. The shortest path to retrieve a material from the PC is automatically determined by the software. Upon completion, this process will form a geodatabase.

When the integration process is complete, the integrated database is published into a local server, ArcGIS Server. Prior to that, minor amendments are performed in the attribute table since some of the information retrieved such as cover book is not complete for every reference material. In addition to that, some of the symbols are not readable by ArcGIS.

ArcGIS Viewer for Flex is then used to view the published data. In this stage, SBSL system is created whereby the interface of the system is designed to include search function.

\section{RESULTSAND DISCUSSION}

This section discusses the results obtained from the study. Fig. 5 and 6 show the complete digitized floor plan of PTAR 1 on level 4 and 5 respectively. 


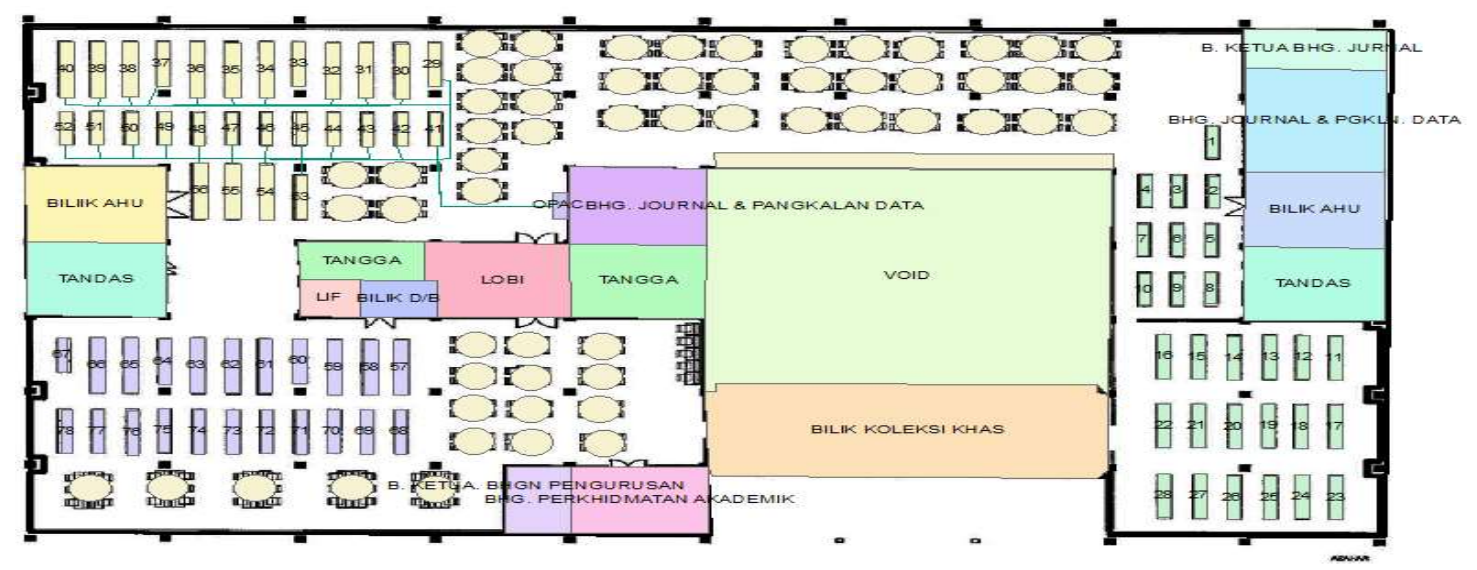

Fig.5. Result of digitizing the floor plan of PTAR 1 at level 4

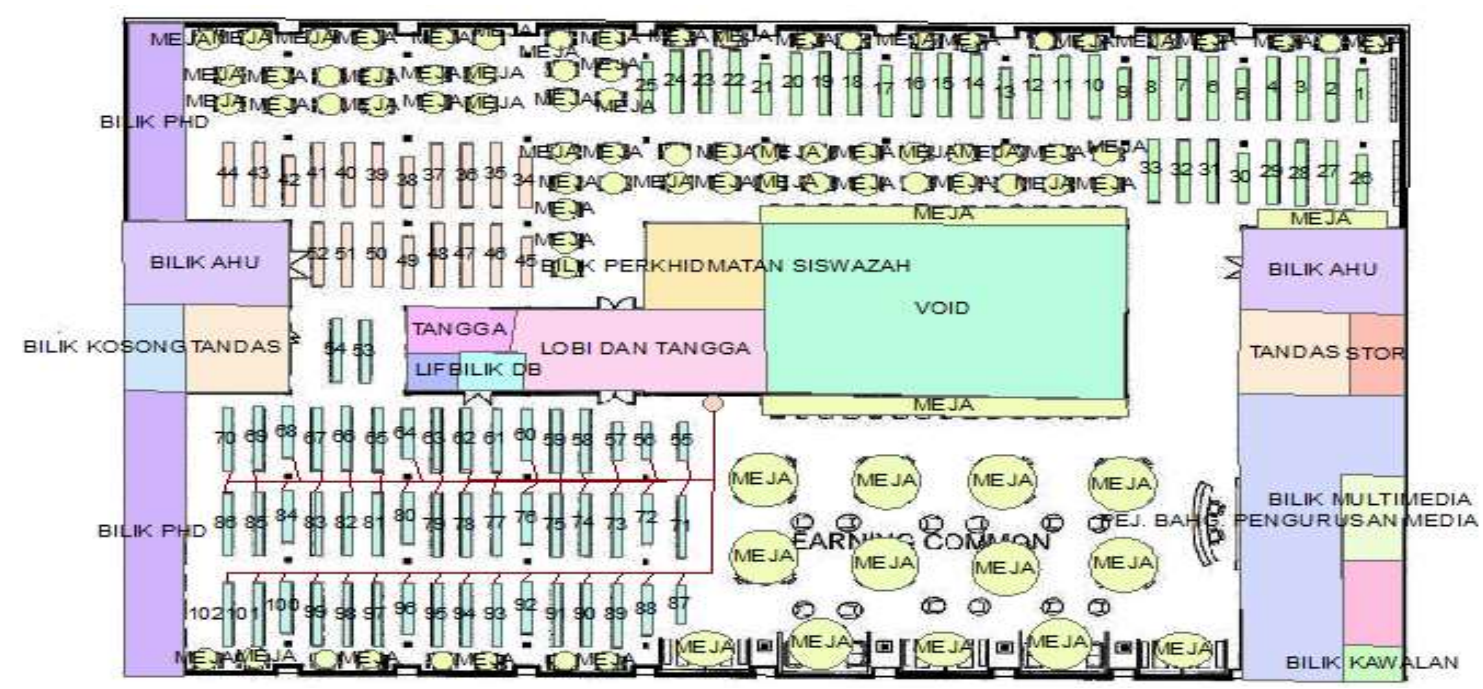

Fig.6. Result of digitizing the floor plan of PTAR 1 at level 5

A screen shot of attribution table developed in ArcGIS 10.1 is illustrated in Fig. 7. The table contains information of reference materials available at PTAR 1 such as title of book, name of author, book availability, category and many more. 


\begin{tabular}{|c|c|c|c|c|c|c|}
\hline \multicolumn{7}{|c|}{ Table } \\
\hline \multirow{2}{*}{\multicolumn{7}{|c|}{ 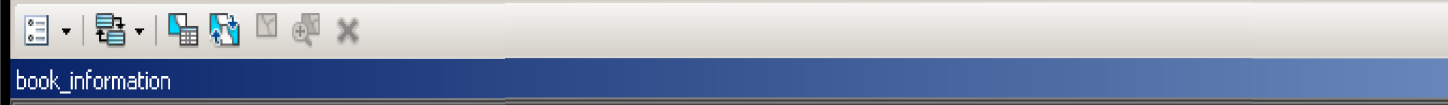 }} \\
\hline & & & & & & \\
\hline & OB.JECTID * & rack_no * & title & categorie & author & zone \\
\hline 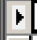 & 1 & \multicolumn{2}{|c|}{$\begin{array}{lll} & \text { soal jawab undang-undang syarikat }\end{array}$} & sains sosial & ahmad awang & B1 \\
\hline & 2 & & beyond the botton line & sains sosial & jack berlin & B1 \\
\hline & 3 & & Excel 2007 & sains sosial & allbert tan & B1 \\
\hline & 8 & & Engineering Electromagnetic & sains sosial & Milliam H. Hayt & B1 \\
\hline & 9 & & 3 Information To HUman Nutriet & sains sosial & Michel J.Gikney & B1 \\
\hline & 10 & 4 & Dictionary of Pesticides & sains sosial & Prattek Mittal & B1 \\
\hline & 11 & 4 & General Ecology & sains sosial & David T. Krohne & B1 \\
\hline & 12 & 4 & Concept of Genetic & sains sosial & William S. Klug & B1 \\
\hline & 13 & & Physical Chernistry & sains sosial & Robert G.Mortimer & B1 \\
\hline & 14 & 6 & Cracking Creativity & sains sosial & Wichel Wichako & B1 \\
\hline & 15 & & 4 Motivation and Leadershipa at Work & sains sosial & Richard M.Steer, Laynan & B1 \\
\hline & 16 & & Fundamental of selling & sains sosial & Charless M. Futrel & B1 \\
\hline & 17 & 6 & International Marketing & sains sosial & Philip R Cateora & B1 \\
\hline & 18 & 4 & Audting An Assertion Approach & sains sosial & Donald H.Taylor & B1 \\
\hline & 19 & 3 & Business Marketing & sains sosial & Edward G. Briety & B1 \\
\hline & 20 & 5 & Accounting Principle & sains sosial & Weygandi & B1 \\
\hline & 21 & 4 & Management Control System & sains sosial & Robert N. Anthory & B1 \\
\hline & 22 & 3 & Excellence in Business Communications & sains sosial & Jhon Y Thil & B1 \\
\hline & 4 & 19 & construction and development & sains dan teknologi & Bernard HWang & 82 \\
\hline & 5 & 22 & Gps satellite and surveying & sains dan teknlogi & Alfred Lieck & B2 \\
\hline & 6 & 26 & Design GLI Application & sains dan teknologi & Alex Leanen & $\theta 2$ \\
\hline & 7 & 27 & XML Eeginers & sains dan teknologi & Mo Grow Hill & B2 \\
\hline
\end{tabular}

Fig.7. Attribution table created in ArcGIS

An example of navigation path to a reference material from a designated OPAC PC created by the software following the linkage is shown in Fig. 8.

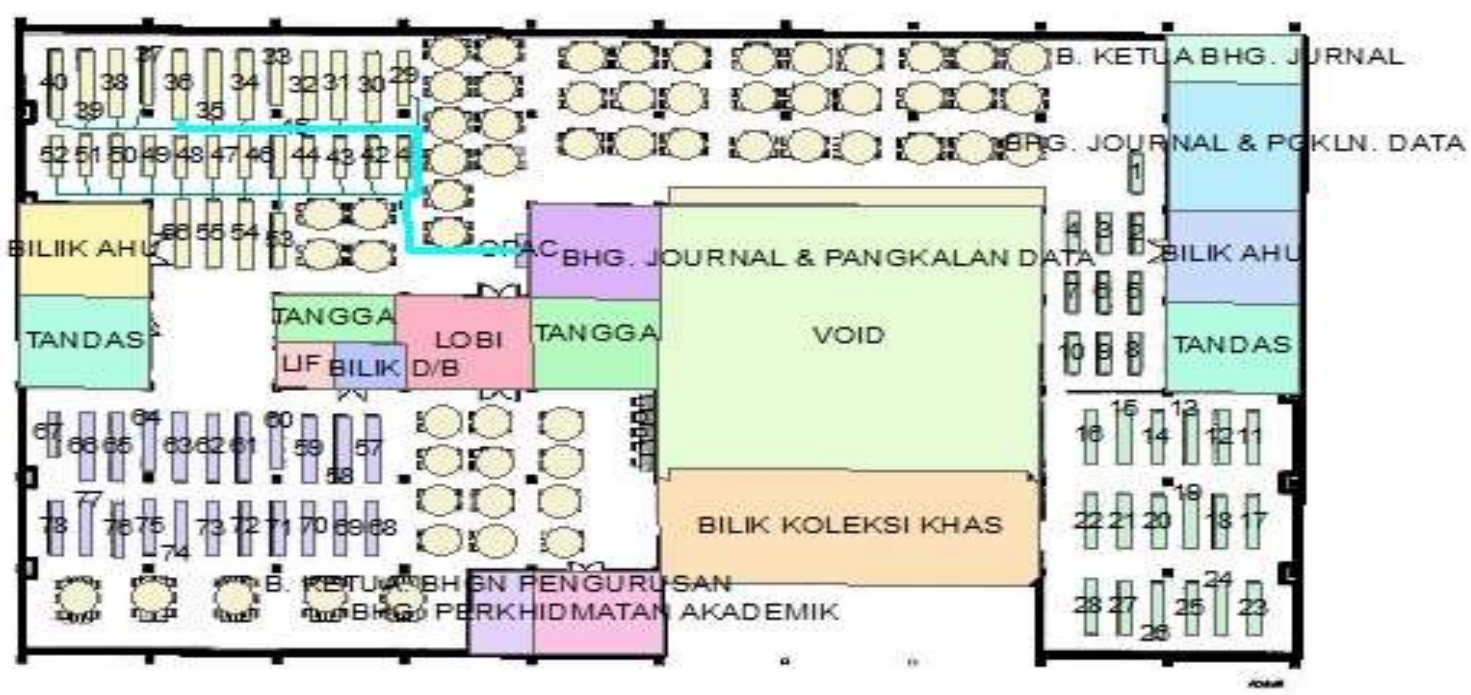

Fig.8. Accurate route from OPAC PC to desired reference material

The developed geodatabase named Library Management appears on ArcGIS Server upon successful publishment as indicated in Fig. 9. 


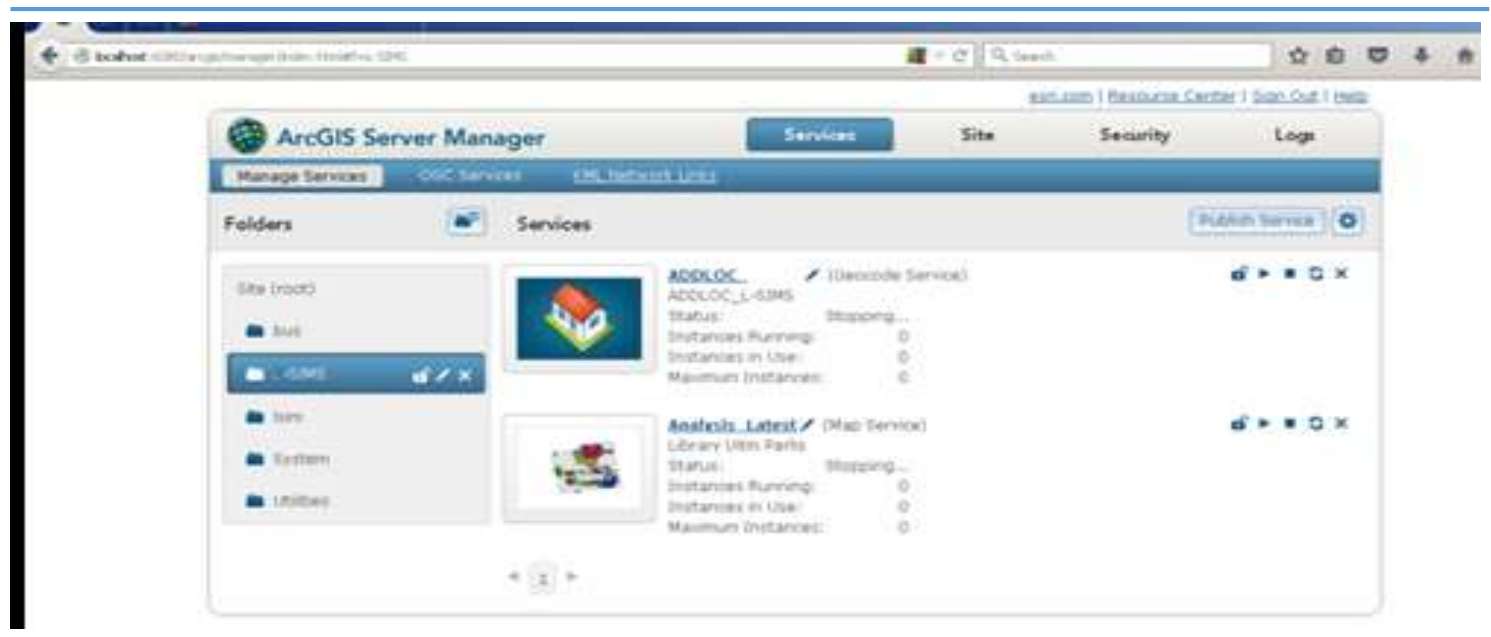

Fig.9. Data Library Management on ArcGIS Server

The published database is viewed using ArcGIS Viewer for Flex and the interface is designed to include search function.

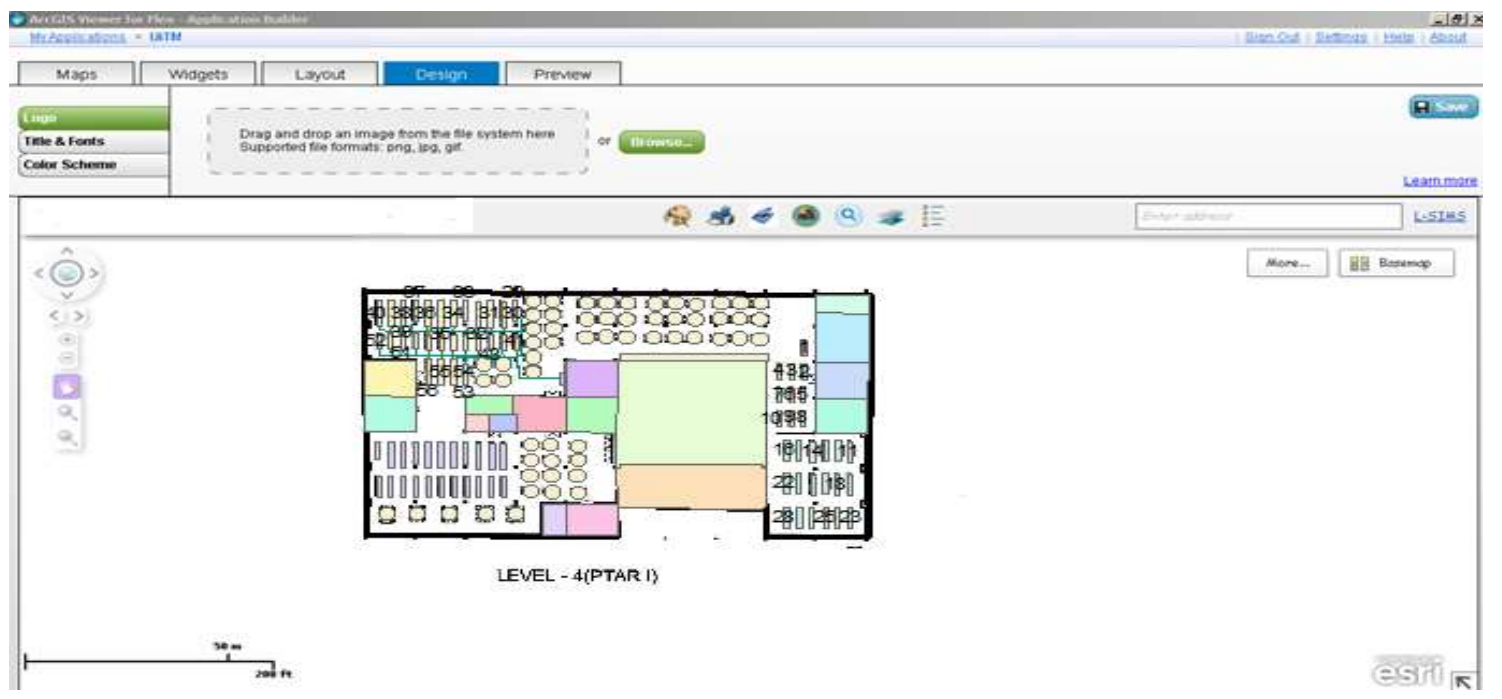

Fig.10. Interface published onto the server

\section{CONCLUSION}

In conclusion, the proposed SBLS has been successfully designed and developed for PTAR 1. SBLS is not only useful to visitors of the library; it is also a convenient tool for librarian. The 2-D map visualisation of desired reference material's location through SBLS eases the process of retrieving, hence minimizing the possibility of not finding it. In the future, the system can be further proposed to be applied at all UiTM's network of libraries. 


\section{ACKNOWLEDGEMENTS}

The authors would like to thank Faculty of Electrical Engineering, UiTM and PTAR 1 for their valuable support.

\section{REFERENCES}

$$
\text { Merriam-Webster. }
$$

2017.

Definition

of

library.

http://www.merriam-webster.com/dictionary/library

[2] Chowdhury G G. Digital libraries and reference services: Present and future, Journal of Documentation, 2002, 58(3):258-283

[3] Asian Scientist. Xiaotuthe talking robot "censored" by Tsinghua University for bad language.

http://www.asianscientist.com/2012/02/academia/tsinghua-university-xiaotu-talking-robot-20

12

[4] GoodchildF. Twenty years of progress: GIScience in 2010.Journal of Spatial Information Science, 2010,1(1):3-20

[5] Bazlan M J, Abdul R A R. Development of geographical based library information system (GeoLIS).In IEEE Control and System Graduate Research Colloquium, 2012, pp. 248-252

[6] Buscema M, Terzi S, Maurelli G, Capriotti M, Carlei V.The smart library architecture of an orientation portal.Quality and Quantity, 2006, 40(6):911-933

[7] Bishop B W, Mandel L H, McClure C R. Geographic information systems (GIS) in public library assessment.LIBRES: Library and Information Science Research Electronic Journal, 2011, 21(1):1-19

[8] Mandel L. Geographic information systems: Tools for displaying in-library use data.Information Technology and Libraries, 2010, 29(1):47-53

[9] Wildemuth B. Post-positivist research: two examples of methodological pluralism. Library Quarterly, 1993, 63:450-468

\section{How to cite this article:}

Ya'acob N, Abdullah S, Yusof A L, Naim N F, Zainali M A. Smart book locator system based on geographic information system at perpustakaan tun abdul razak 1, uitm shah alam malaysia. J. Fundam. Appl. Sci., 2017, 9(5S), 310-319. 